\title{
Disasters
}

\section{...in Egypt}

By Walter ARMBrust

In Egypt, as everywhere else, accidents happen. Whether or not accidents qualify as disasters is an undefinable matter or scale and frequency; one knows them when one sees them. In any event, automobile, train, airplane, and maritime accidents; buildings falling, and floods: all of them occur in 2016. Egypt is in a seismically active area, but thankfully no deadly earthquakes occur, though the popular astrologer Nevin Abū Shāla had predicts at the beginning of the year that a deadly tremor would strike Egypt. Many of the disasters that actually do occur could be called acts of God, and yet quite a few people do not believe that all disasters "just happen." Youtubers continue to upload a video of television presenter Tāmir Amīn warning the public of the awesome power held by something called "al-Majlis al-A'là lil-'Ālam”- the supreme council of the world [ TTrue = False (Life in Limbo)]:

In the next few years these countries and their intelligence agencies, and the Supreme Council of the World, have said that they will destroy countries without starting wars with them, for example that they'll send a tsunami like the one that Indonesia had a few years ago, and that these will completely annihilate countries, drown them or cause floods in their cities and kill thousands. They can make earthquakes by manipulating the Earth's crust in a specific city or country. They can produce a destructive earthquake - 6,7 or 8 on the Richter Scale - and flatten an entire city. Or set off volcanoes that had been dormant in some places.

Tāmir Amīn is not everyone's cup of tea. By 2016 his "Supreme Council" monologue is a re-tread from late 2015, when he was a popular target of satire on social media [ $\nearrow$ Social Media] [ Inferiority = Superiority (Satire)]. In 2016 the spirit of Amīn's conspiracy talk retains enough currency that Șalāh 'Abd al-Șādiq, head of the Egyptian State Information Service, advocates banning the children's cartoon Tom and Jerry on grounds that it promotes violence and terrorism. A newspaper article reports on this development. Its headline proclaims that Tom and Jerry have now joined the Supreme Council of the World. It is safe to say that many people find the idea of weather modification and the inducing of earthquakes and volcanoes - techniques of "Fifth Generation Warfare" according to Aminn's video- to be farfetched. Connecting such powers to the beloved Tom and Jerry strikes many as dubious, to say the least.

However, skepticism toward the most bizarre conspiracy theories is not incompatible with the view that not all disasters are random occurrences or acts of God, unforeseeable by human beings. Some are clearly terrorist acts. Others are more ambiguous. " $B i-f i c l f \bar{a} i l$ "- someone did it — but the agent of such disasters is not always clear. The phrase $b i-f i c l f \bar{a}^{c} i l$ sounds like a grammatical rule, but in 2016 it is invoked most often in reports on a spectacular fire that occurred in the central Cairo district of al- ${ }^{-}$Ataba. The point is that many people who work and live in the area believe that the $f \bar{a}^{c} i l$ - the agent — of this fire is an arsonist. 
The reason that suspicion of arson comes so easily in this case is complex. It has to do with 'Ataba's position in the city, with its reputation, and with its relation to contiguous parts of the city. Generally speaking, an 'ataba is a threshold, which is to say a space of transition, like the door of a house, or a gate between two different spaces. The neighbourhood of al'Ataba takes its name from a palace, al-'Ataba al-Khadirā', which was owned by a relative of Muhammad 'Alī Pasha, the Ottoman general credited as the founder of modern Egypt. But in modern times al-'Ataba has evolved into an actual threshold befitting its name. It is the heart of a broad zone of transition between two districts that are of special concern to the state. One is "Islamic Cairo," stretching from the medieval walled city to the north to the Khalifa district at its southern end. The other is "Khedivial Cairo," the colonial city built between the banks of the Nile and the ancient city that had been inhabited for centuries before Europeans dominated Egypt between the mid-19 ${ }^{\text {th }}$ century and independence in 1952. "Khedivial Cairo" is conventionally glossed as "downtown" [ $\nearrow D$ Downtown/Centre-ville]. Between downtown to the west and Islamic Cairo to the east lies a zone that had once consisted of lakes, orchards and palaces before the water was drained and all the now-dry land was joined together into the urban configuration that is now Cairo. This central Cairene transition zone includes Bāb al-Sha' riyya, 'Ataba and 'Ābdīn. They are all neighbourhoods just west of Port $\mathrm{Sa}^{\text {cīd }}$ Street (a gently curving road built over a filled-in canal that runs northsouth through central Cairo).

This transition zone between Islamic Cairo and Khedivial Cairo, madly packed with workshops and small factories, is considered the heart of the city's informal commercial sector [ $\left.\lambda^{\prime} A s h w \bar{a}^{\prime} i y y \bar{a} t\right]$. It is particularly famous for its intense crowdedness [ $\lambda$ Zahma]. But for all its frenetic activity, al-'Ataba and the whole belt of neighbourhoods in this central zone is relatively expendable in the visions of urban developers compared to its more illustrious districts to the east and west. This is because the neighbourhoods west of Port Said Street are neither historically important like Islamic Cairo, nor tinged with the Belle Epoque cachet of downtown that makes it important to the state, and at the same a desirable acquisition for private developers. Consequently, there are fears that both the state and private sector want to "develop" "Ataba into extinction. "Cairo 2050," a discredited "vision" for developing greater Cairo has been circulating for about a decade. The plan had largely ignored the central area between Islamic Cairo and downtown. Two pages in a 104-page slide show address 'Ataba and its surroundings. A swathe of Cairo in which hundreds of thousands of people live and work was defined by Cairo 2050 as "wholesale centers" which will be "targeted" for displacement "outside of Cairo."

One may discern a model for the future of 'Ataba in well-publicized plans for a similar district known as the Maspero Triangle. It is a section of Cairo on the Nile Corniche resembling 'Ataba in terms of its informality, its intense crowdedness, and its proximity to downtown Cairo. The Maspero Triangle is well known to be threatened precisely with "extinction by development." Newspapers report favourably on a long-incubating plan to erase the Maspero Triangle:

[the project to develop it] is exemplary, a rare opportunity, perhaps the last one, to exploit an enchanting view overlooking the Nile and saving this historic district that suffers from complete chaos and disintegration.

jais 21 (2021) - Themed Section In2016: *86-*92 
The plan for the Maspero Triangle is more destruction than gentrification. Everything in the existing neighbourhood must go: 14,000 residents, 850 shops, and of course all the buildings. The famous architectural firm Norman Foster and Partners has drawn up a plan to replace the Triangle with something more pleasing. Nominally the residents will be re-housed within their old neighbourhood. A fanciful drawing issued by Foster and Partners imagines a rustic bearded man in a galabiyya, presumably a pre-development resident of the area, pouring himself a coffee on a rooftop veranda, with massive skyscrapers in the distance. The authorities say all the right things about consulting Maspero's residents and preserving their rights. Few of the Maspero Triangle residents are convinced. Norman Foster and Partners are not exactly known as populist architects. Most of the people of Maspero believe that expulsion of the area's residents is in the cards, and that their homes and businesses will be replaced with housing for the super-elite [ $\nearrow$ Affluence $v s$. Destitution].

The anticipated destruction of the Maspero Triangle is a blueprint for a particular kind of urban development - a form of "creative destruction," though its creative benefits are entirely a matter of whether or not one sits in the path of the destruction. Hence a new kind of disaster comes to the fore: disaster capitalism. "Disaster capitalism" is certainly not a term of art in Egypt outside circles of economists and activists. But when 'Ataba's Ruway'i district goes up in flames, vernacular equivalents to disaster capitalism become prominent both in the reactions of those most directly affected by the catastrophe, and in those parts of the media most given to indulge conspiracy theories. The facts that everyone more or less agrees on are these: that the fire began late at night on a Sunday, which is the day off for the vendors and businesses located in the area; that a consequence of this was a relative lack of people present and hence fewer eyes on the street; that the fire began in the Andalus Hotel, most of which is occupied by the offices of businesses that operate in 'Ataba; that the fires rapidly jumped from building to building; that the city's main fire station, located virtually next door to the buildings that caught fire, mobilized a response, but not before some 200 shops and warehouses were destroyed, at a cost of millions of pounds.

The official cause of the fire was an electrical short that occurred as the electricity came back on with a surge after an outage. The victims of the fire often described their losses in resignation verging on cynicism [ $\nearrow$ Hope $\boldsymbol{\nu}$ s. Hell, $\nearrow$ Hope $=$ Hell (Dystopia)]. As one of the larger businessmen affected by the fire put it,

they were spraying water on that hotel, while this building on the right was on fire, and also the one on the left. And the one behind them too. How can they work; they've only got one hose. [the person interviewing him says "the government says it will pay £E 5,000 compensation to each individual] [the man being interviewed grimaces in a quasi-laugh] My storeroom had merchandise worth a million pounds. It's all gone.

It was an understatement to say that not everyone accepted negligence or a simple accident as the actual cause of the disaster. One man interviewed in the same video said flatly that,

you could say something like this was a first-class terrorist operation. The fire didn't start in one place. It was burning here, and here and here [he gestures at the buildings all around him]. ... in half an hour all of that was on fire. Half an hour. This was a terrorist operation against the people, against Egypt. [ ${ }^{\text {"The System" }}$ s. "The People"] 
A young man notes that a similar fire broke out nearby just a week ago. "How could that be? And why in particular on our day off, and at night? Not in the day when there are people around who could have stopped it. That's why I'm telling you, it was a deliberate act."

But if there are suspicions that the blaze is an act of a person and not an act of God or a consequence of negligence, then the question "why?" must inevitably be posed. Quite a few journalists and commentators are eager to take up the challenge of answering this question. In doing so they have the nearby example of Maspero in mind. One points to the government's antipathy to itinerant street vendors, many of whom store their goods in 'Ataba at night and populate busy sidewalks during the day. The state had failed during the Revolution to carry through on a plan to restrict street vendors to certain downtown locations. Now they want to try a similar plan, which is to remove vendors from 'Ataba and Muski and redesign the entire area. This confirms suspicions of a plan to transfer ownership of the area to big investors. Another journalist puts it more bluntly: the fire was started intentionally "in order to clear the area of itinerant vendors and shop owners in preparation for selling it to Gulf Arab investors so that they can build big new malls." The article supports its claim largely with circumstantial evidence. The blaze spread unevenly, skipping over some buildings and catching on in others; the fire brigade, located only 500 meters from the area, sent a truck that contained no water; a similarly suspicious fire had started in the area just a week ago, on the Shamm al-Nasīm holiday, near the Sednaoui (Șidnāwī) department store in the neighbourhood. Sednaoui has been owned by the state since the nationalizations of the Nasser era. Once an icon of middle-class culture, the store is now unprofitable due to its location. A Gulf Arab buyer is said to be interested in purchasing it. Perhaps he wants the land without the old building? Indeed, the article reiterates the story that Gulf investors are interested in the entire area. They want to

transform it into a commercial area along the lines of Dubai, and the Cairo Governorate has agreed to the sale, except for the stumbling block posed by the itinerant vendors and the owners of the shops in 'Ataba and Muski.

And so, at least in the public imaginary, the concept if not the actual term of "disaster capitalism" takes an honourable place next to floods, catastrophic car, train and plane accidents, and earthquakes - all the usual suspects in the pantheon of disasters. 'Ataba may well be the next Maspero Triangle, destroyed in order to save it for the greater good of global capitalism, if not for the good of its current residents. The fire might be part of the plan. Even if it is not, few of those who live or work in central Cairo will feel at ease as the future unfolds.

\author{
Related Entries \\ ARRAYS - 'Ashwā'iyyāt $\downarrow$ Downtown/Centre-ville $\downarrow$ Social Media $\downarrow$ Zahma \\ CODES - Affluence vs. Destitution $\downarrow$ Hope vs. Hell "The System" vs. "The People" \\ CODES ColLAPSED - Hope $=$ Hell $($ Dystopia $) \diamond$ Inferiority $=$ Superiority $($ Satire $) \diamond$ True $=$ False $($ Life in \\ Limbo)
}

jais • 21 (2021) - Themed Section In2016: *86-92 


\section{References}

'ABD AL-LAṬīF, Ahmad, and Muḥammad ABŪ ḌAYF. "Al-Ahālī: Al-Ḥarīq mu'tamad wa-«rizq awlādnā» dạā fì 12 să‘a." al-Wațan, May 10, 2016, <https://www.elwatannews.com/news/details $1159805>$ (accessed October 2, 2018).

'ABD AL-LAṬīF, Aḥmad, Muḥammad SAYF and Gihād al-ṬAwīL. "Kārithat «al-'Ataba»: Iḥtirāq 200 mahall wa-70 makhzanan wa-40 shaqqa." al-Watan, May 9, 2016, <https://www.elwatannews. com/news/details/1159799> (accessed October 2, 2018).

'ABD AL-RĀḌ̄, Rihāâ. "«Al-Dākhiliyya»: Mās kahrabā̄ī warā’ «harīq al-'Ataba».” Al-Waṭan, May 9, 2016, <https://www.elwatannews.com/news/details/1158866> (accessed October 2, 2018).

'ABD AL-WAнHĀB, Sanā’. “Al-Iḥsāà fī taqrīr «al-Sayyārāt wa'l-qițārāt» li-'ām 2016: Akbar 'adad alhawādith fī yūnyū." Al-Mașrī al-Yawm, December 31, 2016, <https://www.almasryalyoum.com/ news/details/1065334 > (accessed September 27, 2018).

'ABD AL-WAHHĀB, Walīd. 'Khabīr 'askarī: «naqqār al-khashab» wa-'hārib' abraz barāmij al-jīl alkhāmis lil-hurūb." Al-Mașrī al-Yawm, September 6, 2016, <https://www.almasryalyoum.com/ news/details/806309> (accessed October 1, 2018).

'ĀDIL, Iḥsān. "Bi 'l-vīdiyō: Mamdūḥ Hạza: yatimm al-ān tanfîdh mukhațtat al-Qāhira 2050 wa-bay ihā lil-Yahūd.” Nujūm Miṣriyya, May 13, 2016, > https://www.nmisr.com/arab-news/egypt-news/-bخطa (القاهرة

ASHRAF, Nifīn. "Ba'd ittihām «Tūm wa-Jīrī» bi-nashr al-'unf bi'l-mințaqa narșud abraz tașrīhāt āthār istiyā̄ al-mișriyyīn, abrazuhā «jāsūsiyyat Abla wa-Fāhītā» wa-«Majlis idārat al-'ālam»." Al-Dustūr , May 9, 2016, <https://www.dostor.org/1060215> (accessed October 1, 2018).

[AșwātMișriyya $]=$ "Sab'at as'ila 'an ikhtifă’ țā'irat al-rihla 804 li-Mișr lil-Ṭayarān". Așwāt Mișriyya May 19, 2016, <http://www.aswatmasriya.com/news/details/62829> (accessed May 27, 2018).

'ĀṬIF, Muhammad. “Al-Kūmīdiyā al-Sawdā’: Tūm wa-Jīrī yanḍammān li-majlis idārat al-cālam.” Aṣwāt Mișriyya, May 5, 2016, <http://www.aswatmasriya.com/news/details/62362> (accessed October 1, 2018).

[Egyptianomics] = "Ūbir wa'l-siyāsa wa-fashl al-tadmīr al-khallāq fĩ Mișr." Egyptianomics Blog, March 18, 2018, <https://tinyurl.com/y7urv9qp> (accessed October 2, 2018).

FARANSīs, Fādī. “Al-Dhikrā al-ūlā li-ḍahāyā al-țā̉ira al-rūsiyya fỉ Sīnā’ ... Al-Safîr Sīrgay Kīrītshīnū: Nantaẓir ta’mīn al-mațārāt bi-nisbat 100\% li-'awdat al-siyāḥa." al-Maṣrī al-Yawm, September 30, 2016, <https://www.almasryalyoum.com/news/details/1032684> (accessed October 2, 2018).

FĀRŪQ, Usāma. "Harīq al-Qāhira 2016: 'Ușūr al-tahawwul tabda’ min al-'Ataba!” al-Mudun, May 12, 2016, <https://tinyurl.com/y8h97mdf> (accessed October 2, 2018).

GAMĀL, Dīnā. "«Ḥurūb al-jīl al-rābi'» tuḥāṣir Mișr.” al-Dustūr, March 26, 2016, <https://www.dostor org/1015553> (accessed October 1, 2018).

al-ḤABBĀL, Ayāt. "Hawādith inhiyār al-'aqārāt fī muhāfazāât Mișr." Al-Mașrī al-Yawm, January 14 2016, <https://www.almasryalyoum.com/news/details/873750> (accessed September 27, 2018).

al-Ḥ̂ABĀL, Ayāt, and Ḥamdī QĀSIM. "Al-Sijn min sanatayn ilā 14 sana li-56 muttahiman fī «Gharq markib Rashīd»." Al-Mașrī al-Yawm, March 26, 2016, <https://www. almasryalyoum.com/news/ details/1107778> (accessed September 27, 2018).

ḤASAN, Wafă̄. "«Fūstir ānd bārtinīrz»: al-Tārīkh al-sirrī lil-sharika al-brițāniyya allatī tasta idd litashrīd sukkān «muthallath Māsbīrū»." Al-Mūjaz, January 15, 2016, <http:/www.elmogaz.com/ node/257038> (accessed October 2, 2018).

[el-HefnAwi, Ayman (?)] "Cairo Vision 2050: The Strategic Urban Development Plan of Greater Cairo Region.” [n.d.], <http://mirror.unhabitat.org/downloads/docs/8635_42944_AymanElhefnawi.pdf $>$ (accessed October 2, 2018).

jais • 21 (2021) - Themed Section In2016: *86-*92 
HINDĀWĪ, Hāshim. "al-Ta'bi'a wa'l-iḥṣā': Irtifăc ḥawādith al-sayyārāt 'alà 'l-țuruq ilā 7 ālāf fĩ 2016." alWațan, December 31, 2016, <https://www.elwatannews.com/news/details/1735121> (accessed September 27, 2018)

[al-Hurra ] = "Suyūl Miṣr al-ārima: 22 qatīlan wa-72 jarīḥan." Al-Hurra, October 30, 2016, <https:// www.alhurra.com/a/egypt-rain-/331770.html> (accessed September 27, 2018).

IBRĀHĪM, Ibrāhīm 'Abd al-Mun 'im. "Aswār al-Qāhira wa-abwābuhā al-qadīma: raw'at al-tașmīm washumūkh al-'imāra.” Al-Hay’a al-'āmma lil-isti lāmāt: Bawwābatuk ilā Miṣr, November 3, 2016, $<\mathrm{http}: / /$ sis.gov.eg/Story/130937?lang=ar> (accessed October 2, 2018).

IBRĀHĪM, Ibrāhīm 'Abd al-Mun'im. "Shawāric al-Qāhira al-Fāțimiyya: 'Abiq al-Tārīkh wa-raw'at altașmīm wa-khulūd al-'imāra." Al-Hay'a al-'āmma lil-isticlāmāt: Bawwābatuk ilā Miṣr, June 15, 2016, <http://www.sis.gov.eg/?lang=ar> (accessed October 2, 2018).

IBRĀHĪM, Ibrāhīm 'Abd al-Mun'im. "Shawāri' al-Qāhira al-Khid̄̄wiyya: Raw'a wa-fakhāma." Al-Hay'a al-'āmma lil-isti lāmāt: Bawwābatuk ilā Miṣr, June 25, 2016, <http://www.sis.gov.eg/ Story/123759?lang=ar $>$ (accessed October 2, 2018).

KAMĀL, Aḥmad. "Nakshif al-ḥaqā’iq kāmila fĩ mu’āmarat harīiq al-'Ataba." Al-Nidā’, May 11, 2016, $<$ http://www.elnedaa.com/t 46386> (accessed October 2, 2018).

KĀMIL, Nifīn. "«Al-Ismācîliyya lil-'Aqārāt»" tista’nif anshițat «tațwīr» 'imārāt wusṭ al-balad." AlShurūq, May 31, 2016, <http://www.shorouknews.com/news/view.aspx?cdate=31052016\&id= aa1fe6a4-3a3e-44e2-ab9a-372d8e5aabfb> (accessed October 2, 2018).

KHAYR, Muḥammad. "Tațīir muthallath Māsbīrū: Hākadhā yumkin istithmār al-Qāhira al-tārīkhiyya." al-Mașrī al-Yawm, February 11, 2016, <https://www.almasryalyoum.com/news/details/ 891254> (accessed October 2, 2018).

al-LABŪDĪ, Rīhām. "Taqrīr li-«Nahār Jadīd» 'an harīiq al-Ruwaycī: al-Mashhad «kharāb» wa-ahạad alḍaḥāyā dakhal li-yunqidh bị̣ā'at shaqīqih fa-kharaj juththa." Al-Bidāya, May 11, 2016, $<$ http://albedaiah.com/news/2016/05/11/112858> (accessed October 2, 2018).

MĀHIR, Muștafà. "Aqwā 5 zalāzil ḍarabat Miṣr khilāl al-qarn al-māộ̄.” YallaFeed, May 17, 2016, $<$ https://yallafeed.com/aqwa-5-zlazl-dharbat-msr-khlal-alqrn-almadhy-3639> (accessed September 27, 2018)

al-MANSī, Rashā. “Akhțaruhā tata'allaq bi-șiḥhat al-Sīsī: Aghrab tanabbu’āt al-falakiyyīn fī 2016; mādhā taḥaqqaq minhā?" Al-Fajr, December 7, 2016, <https://www.elfagr.com/2377625> (accessed September 27, 2018)

[MY Oct14] = "Imārāt wusț al-balad al-tārīkhiyya: Hākadhā taghayyarat Miṣr fĩ qarnayn.” al-Mașrī alYawm, October 14, 2016, <https://www.almasryalyoum.com/news/details/1024119> (accessed October 2, 2018).

RĀGHIB, Dīnā. “'alà Khuțà Tshīlī: Miṣr ka-tajriba jadīda lil-'ilāj bi'l-ṣadma.” Tibyānn, August 28, 2016, $<$ https://tipyan.com/as-chile-egypt-as-new-trial-for-shock-therapy/> (accessed October 2, 2018).

SАмін, Mai. "Developing the Triangle." Al-Ahram Weekly, Issue 1301, June 23-29, 2016, <http:// weekly.ahram.org.eg/News/16688.aspx> (accessed October 2, 2018).

al-SAYYID, Āya. "Sirr tasmiyat al-'Ataba al-Khaḍrā’ wa'l-ism al-awwal lahā." Nujūm Miṣriyya, August 30, 2016, <https://tinyurl.com/y8r3kswl> (accessed October 2, 2018).

SHAKran, Khalid. The Uneven City: Planning Insurgencies in Ramlet Bulaq and Maspero Triangle. MA Thesis, University of California Irvine, 2016, <https://cloudfront.escholarship.org/dist/prd/ content/qt2441k3s4/qt2441k3s4.pdf> (accessed October 2, 2018).

SHAMmĀ', Muhammad. "Al-'Ataba: «Dawla dākhil dawla».” Al-Mubtadā, May 12, 2016, <https:// www.mobtada.com/details/468707> (accessed October 2, 2018).

jais 21 (2021) - Themed Section In2016: *86-*92 
SHAMмĀ̄, Muḥammad. “Al-'Ataba: Dawlat al-khamsa milyārāt junayh.” Al-Yawm al-Jadīd, May 17, 2016, <http://www.elyomnew.com/news/inside/2016/05/17/52910> (accessed October 2, 2018).

al-SHARQĀWĪ, Amīra. "Ba`d izālat manzilayn: Ahālī «muthallath Māsbīrū» yatakhawwafūn min ḍiyāe hịlm mashrūc al-tațwīr wa-yuhaddidūn al-tașīid." Al-Ahrām, February 24, 2016, <http://gate. ahram.org.eg/News/861919.aspx> (accessed October 2, 2018).

SzENASY, Susan. "Can we afford to leave locals out of urban regeneration?" Metropolis, Feb. 9, 2016, $<$ https://www.metropolismag.com/cities/planning-cities/leaving-locals-out-urban-regeneration/> (accessed October 2, 2018).

[Taḍ̄̄mun Aug14] = "Al-Khalīfa”. Taḍāmun, August 14, 2016, <http://www.tadamun.co/?post type $=i$ ty $\& p=8487>($ accessed October 2, 2018).

[YT Apr23] = "Tāmir Amīn, Majlis Idārat al-`Ālam". Youtube video, uploaded on April 23, 2016, $<$ https://www.youtube.com/watch?v=3NrMoxQ7C5M> (accessed October 1, 2018).

[YT Jan01] = "Tanabbu'āt 'ālimat al-falak Nīfīn Abū Shāla li- ām 2016." Youtube video, uploaded on January 1, 2016, <https://www.youtube.com/watch?v=vP5gslCKOBU> (accessed September 27, 2018).

[YT May05] = "Tūm wa-Jīrī muttahimān bi'l-irhāb". Youtube video, uploaded on May 5, 2016, <https:// www.youtube.com/watch? $\mathrm{v}=\mathrm{TTZy} 386 \mathrm{LhHQ}>$ (accessed October 1, 2018).

[YT May10] = “Tujjār al-'Ataba 'an ḥarīq «al-Ruway'ī»: il-Ḥādith 'amaliyya 'irhābiyya, wi'l-mațāfî qaālit mafìsh mayya." Al-Bawwāba Vidyū (Youtube), uploaded on May 10, 2016, <https://www. youtube.com/watch? $=$ XidFlO0G4k8 $>$ (accessed October 2, 2018).

walter.armbrust@sant.ox.ac.uk 